\title{
How to Cultivate Intercultural Communication Awareness in Postgraduates English Teaching

\author{
Xue-mei WANG ${ }^{1}$ and Ying $\mathrm{LI}^{2}$
}

${ }^{1}$ No.206, Guanggu $1^{\text {st }}$ Road, East Lake Hi-Tech Development Zone, Wuhan, Hubei, China 430205

${ }^{2}$ No.206, Guanggu $1^{\text {st }}$ Road, East Lake Hi-Tech Development Zone, Wuhan, Hubei, China 430205

Keywords: Intercultural communication, Intercultural communication awareness, Postgraduates' English teaching.

\begin{abstract}
As the arrival of economic globalization age, some new and higher requirements on cultivation of intercultural communication ability are urgently needed. How to cultivate intercultural communication awareness and competence has become the main task in university English teaching, especially for postgraduates. This thesis starts from the importance of intercultural communication awareness and its definition in postgraduates English teaching; analyses its current existing problems and causes, and then explores and proposes some effective approaches to develop intercultural communication awareness in postgraduates English teaching.
\end{abstract}

\section{Introduction}

As the rapid development of economic globalization, the intercultural communication becomes much more frequent than ever before. The increasing intercultural communication calls for the English learners with not only language abilities but also intercultural communication awareness. Nowadays, it is widely recognized that the ultimate goal of English education is to develop learners' intercultural communication competence. To achieve this goal, culture teaching should be integrated into English teaching. So far, many researchers have investigated intercultural communication awareness of English learners, and provided some culture teaching approaches to develop students' intercultural communication awareness. However, the object of research is mostly related to primary, middle school students or college undergraduates, and seldom to postgraduates. And postgraduates' stage is the golden time for technology creation and thinking innovation. The students need to read and receive plenty of external culture information for their further research, and intercultural communication awareness becomes particularly much more important under this circumstance. So this thesis will propose some effective approaches to develop post students' intercultural communication awareness on the perspective of teacher, students, curriculum setting and campus culture. Hope it can provide some useful suggestions for reference.

\section{Necessity of Intercultural Communication Aware ness in Postgraduates English Teaching}

The enrollment of graduate students has been largely increased since 1999, with an average rate of $26.9 \%$ increased each year.[1] The expansion of graduate education forced today's postgraduates have to face more competitions and challenges in the further career, such as the fierce competition from their peers - all this calls for the students to gain not only specialized knowledge but also intercultural communication awareness competence to obtain a competitive place in the society. As for 
postgraduates, their main job is to acquire abundant knowledge and information to launch their own research. Some postgraduates will go abroad for further study and work after graduation. They will attend academic research activities and international communication, express and communicate their own views with people from different countries and culture. So in order to keep up with the times and academic research's needs, they have to a good command of intercultural communication competence when use target language to communicate with people. Therefore, equip postgraduates with intercultural communication competence become very necessary and important in English teaching. [2]

\section{Definition of Intercultural Communication and Intercultural Communication Awareness}

The term "Intercultural Communication" was first used in Edward T. Hall's book The Silent Language in 1959. Most researchers think that intercultural communication is the interpersonal communication between people from different cultures [3]. Gudykunst and Kim [4] define intercultural communication as 'a transactional, symbolic process involving the attribution of meaning between people from different cultures'. Samovar [5] point out that intercultural communication occurs when a member of one culture produces a message for consumption of a member of another culture. In conclusion, intercultural communication refers to a process and phenomenon that native language people communicate with non-native language people for thoughts, emotion and information, what' more, it is also an information interaction between people from different culture backgrounds. On account of the difference of cultural phenomenon, customs, values, thinking and religion, it easily leads to misunderstandings and conflicts, especially on the view of the same word and sentence. In order to minimize these misunderstandings and conflicts, a positive attitude, to understand and accept cultural diversity and distinction, has to be built in our mind. And this is called intercultural communication awareness.

\section{Existing Problems on Intercultural Communication Awareness}

Since influenced by Chinese tradition English teaching methods, a misunderstanding is occurred during English learning. That is no obstacles exist in intercultural communication if master language pronunciations, words and grammar, but the truth tells us it is completed wrong. Actually, it is much more embarrassed if make culture mistakes than grammar mistakes during the intercultural communication. Because grammar mistakes can be forgiven, however, the cultural mistake is usually recognized as impoliteness. So the author summarizes some problems on intercultural communication awareness as follow.

\section{Pay Much Attention to Study Language Instead of Culture}

Due to restricted by linguistic theory development, the importance of cultural education is always ignored in English teaching. The university and research institutions seldom take effective action to put cultural education in an important place. As a part of college English education, postgraduates' English teaching continues its traditional grammar-translation method, which puts strong emphasis on the learner's grammatical competence while ignoring culture elements in foreign language learning. Such a method results in the inefficiency of postgraduates' English education. So this is why someone passed CET4 and CET6 still could not communicate with foreigner smoothly or exchange their views very properly; and it can also explain that why some graduate students feel uncomfortable and embarrassed 
when communicate with foreigners. Actually, it is not difficult to find out caused lead to the ignorance of language teaching instead of culture teaching. There are two main reasons; one is the teacher and professor in university. Nowadays, the teachers and professors pay too much attention to research instead of teaching, some of them even do not realize the importance of cultural teaching, and so they are not willing to spend time to set new cultural teaching for non-English major postgraduates. Another one comes from society. The main method to measure one's English competence in some company is whether passed CET4 or CET6 instead of actual intercultural communication competence. These factors seriously restrict the developments of postgraduates' intercultural communication awareness.

\section{Different Culture and Values Lead to Improper Usage of Words}

The language is the most important carrier of culture, while culture is the core of a language. It is impossible to master a language without understanding its nations' culture.

So the international communication can not be realized and developed. Due to different society environments in nations and countries, the way of thinking, language habits, culture and customs are varies from each other. It will easily cause conflicts on cultural if lack intercultural communication awareness and rarely understand the way of expression in target language. For example, a student abroad named Gao, he recalled his work experiences in one British company. He was judged as an aggressive man who disrespected others' opinion and views. And he fell into deep thinking that why his boss and colleague judged him like this. Fortunately, he finally found out the reason when he argued with his boss. The manager said that he disrespect the suggestions from leader and refuted for several times. Gao explained that 'I didn't mean that...' No matter how Gao explain, the manager did not listen to him. Actually, if Gao thought carefully, he would find out the answer. Chinese usually likes straightforward manners, when heard some different opinions, they will say straightly: 'No, not right, what, impossible and so on.' So Gao expressed his points by using this straight words when heard some different opinions, like: 'No.... Wrong or I don't think so...' While for British people, their expression way was opposite, they will use implicit words rather other straight words. Like, 'I am afraid, I can't agree with you and so on. Therefore, according to this example, only understand values and culture features of other country, it can create a good environment for intercultural communication.

\section{Intercultural Communications Restricted by Environments}

Nowadays, the native intercultural communication is limited in class, which lack of real and effective language environments. And postgraduates students usually understand and express their thoughts based on native language culture; therefore, it often makes some misunderstandings and troubles when communicate with people from other country. However, postgraduates are different from undergraduate, they have enough time to arrange and have some opportunities to attend academic conference, where provides an excellent place to contact with people from external culture. In that case, it will promote the developments of intercultural communication awareness by learning and accumulating this kind of communication experience. 


\section{Effective Approaches on Cultivating Intercultural Communication Awareness}

\section{Train Highly Qualified Teacher Team}

The complexity of culture requires that a language teacher is not only a transmitter of knowledge but also a mediator of different cultures. Unfortunately, most language teachers in China lack adequate knowledge about the target culture and intercultural communication as well as the corresponding techniques for teaching culture. Gonzalez [6]points out that language teacher need to be trained regarding the cultural aspect. If language teachers must help learners develop cultural quality and intercultural communication competence, it is insufficient that they only improve language teaching methods. They also need to involve themselves in the study of both the target culture and the native culture and know how to conduct culture teaching by adopting a variety of teaching techniques flexibly to meet the needs of cultivating students intercultural communication awareness. Therefore, training language teachers for culture teaching is an urgent and absolutely necessary task in current English teaching. To train qualified teachers for the successful implementation of intercultural communication awareness, it is suggested that a teacher training program be designed for English teachers. When designing teacher training program, goals, content and teaching strategies and evaluation need to be taken into consideration. It should be accommodated to the practical situations of culture teaching so as to meet the needs of language teachers from different institutions.

\section{Develop Students' Autono mous Learning Competence}

As for postgraduates, their courses are much less than undergraduates'. So they have a lot of time to arrange and schedule. English teaching is far from enough to learn foreign country culture. So we need to find other methods to strengthen the development of intercultural communication awareness. And autonomous learning is one of best choice for post students. It requires students have serious self-control ability. They have to learn and grasp the inner meaning to accumulate culture knowledge. For example, to study and comprehend culture contained in words, grammar, listening, reading and writing. Or realize the culture difference carefully when watch movies and listen to songs. In the practice of study, the students will be acquainted with history, customs and technology of other country, and know the linguistic style, expression and features. Thus, it can exclude obstacles caused by culture insufficiency when communicate with foreigners.

\section{Design Curriculum on Intercultural Communication}

The misunderstandings and conflicts in intercultural communication are caused by insufficiency for external culture knowled ge. The core of intercultural communication is to reach efficiency of culture communication and exchange. And it needs both sides are familiar with target language context. Therefore, it is very essential to design curriculum on intercultural communication in university. Some typical cases related Chinese and Western cultures should be added into the curriculum. It is easily understand and accepted by students. In addition, some elements ought to be considered when design concerned course. Such as, individual's English levels, interests, character features and so on. What' more, the curriculum should collect substantial materials; integrate with the social reality, and emphasize the contrast between Chinese and Western culture. In that case, students can be aware of cultural connation. And the course also includes different field in culture. Such as, target 
language's social and economic system, religions, customs, philosophy, history, art and literature. These kinds of courses, like 'Communication Arts and Sciences', or 'Intercultural Communication Skills" and some related curriculum, they would help students fully understand the necessity of intercultural communication; strength the sensitiveness for distinction of culture, and then adapt themselves to society to achieve ultimate goal of intercultural communication.

\section{Enrich Campus Culture Life by a Variety of Activities}

Enrich campus culture life is one of important way to cultivate students mind. Such as, launch academic activities on intercultural communication and draw some students abroad to join in, invite some foreigner experts and scholar to do reports, or organize students to go to other university and learn some different cultures to enrich our campus life. Besides, a variety of competition on intercultural communication can be carried out to attract students to participate in it, for instance, the speech debate, recite and translation competition for countries customs and culture. Students could understand and learn more knowledge for country culture, not only broaden their horizon, but also cultivate their minds. This kind of activities sow seeds in students hearts; they will be aware and try to apply into practice unconsciously. So it fundamentally promotes the development of university intercultural communication awareness and competence.

\section{Conclusions}

In summary, the cultivation of intercultural communication awareness and competence is the essential approach to enhance the efficiency of English teaching and develop comprehensive ability. People from different nations and countries will learn from each other and narrow the culture gap when communicate with each other. Under the background of world culture diversity, we should fully understand our Chinese fundamental culture spirit and features, and keep confidence in Chinese culture. To build an open mind to welcome external culture and absorb them to intercultural communication study. Put the intercultural communication awareness into the entire English learning.

\section{References}

[1] Duan Hong. Cultural Teaching in English Teacher for Non-English Major Postgraduates and Intercultural Communicative Competence Development. [J].P11-P12. Shanghai Foreigner Language University (In Chinese)

[2] Gudykunst, W. B. Handbook of International and Intercultural Communication [M]. Thousand Oaks: Sage, 2002.

[3] Gudykunst, W. B. Handbook of International and Intercultural Communication [M]. Thousand Oaks: Sage, 2002.

[4] Gudykunst, W. B. \& Kim, Y. Y. Communicating with Strangers [M]. Boston: McGraw-Hill, 1997.

[5] Samovar, L. A. et al. Communication between Cultures [M]. Beijing: Foreign Language Teaching and Research Press, 2000.

[6] Gonzalez, I. G. Culture Leaching and Second Language Instruction [J]. Overview of Intercultural Education. Teaching and Research, 1978, 3(1): 66-77. 